\title{
Successful genetic transformation in date palm (Phoenix dactylifera)
}

\author{
L. Hassan* \\ Professor, Biotechnology \& Genetic Engineering Laboratory, Department of Genetics \& Plant Breeding, Bangladesh \\ Agricultural University; Mymensingh-02202 Bangladesh, Phone: 0088091 52268, Cell: 00880175 091096, *E-mail: \\ lutfulhassan@yahoo.co.uk
}

\begin{abstract}
The introduction of foreign genes into most of the Phoenix spp using recombinant DNA technology is not a straight forward task. In Phoenix spp application of this technology towards successful transformation proved to be a more difficult one - so far no report on the successful regeneration of transgenic date palm plants has been published. We developed an efficient and reproducible variety-independent method for producing transgenic date palm (Phoenix spp) via Agrobacterium-mediated transformation. Agrobacterium rhizogenes strains LBA 9402 were used and for cotransformation experiments the strain LBA 9402 with the binary vector pBIN19 with the p35S GUS INT gene was used. Off-shoot segments from different Phoenix spp cultivars were infected with Agrobacterium rhizogenes. The development of 'hairy roots' at a high frequency only on infected tissue pieces showed that transformation is possible. Various parameters like, effect of different genotypes on root initiation, root number and root length have been studied. Regeneration of transformed root cultures to plantlets was also attempted. Histochemical GUS assay and polymerase chain reaction analysis of hairy roots confirmed the presence of GUS gene. Agrobacterium tumifaciensmediated transformation was also performed using the leaves of off-shoot explants. Agrobacterium tumefaciens strains: I) GV3101 with the vir plasmid pMP90 the strain C58C1 ATHV with the vir-plasmid pTiBo542 (=pEHA101; Hood et al. 1986) was used. The nptll gene (neomycin phosphotransferase) was used as a selectable marker gene. The $\beta$-Glucuronidase-gene (GUS-Gene: Jefferson et al. 1987) under control of the Ubi- and 35S-Promotors, with an Intron (Vancanneyt et al. 1990), was used as the reporter gene. We also used the genetically engineered Agrobacterium tumefaciens strain LBA4404 as a vector for infection in the transformation experiment, which contains plasmid pBI121 of $14 \mathrm{KDa}$ (binary vector). This binary vector contains following genes within the right border (RB) and left border (LB) region of the construct: The udiA gene (Jefferson, 1986) predetermining GUS ( $\beta$-glucuronidase), driven by CaMV promoter and NOS terminator. This reporter gene can be used to assess the efficiency of transformation. The nptll gene (Herrera-Estrella et al., 1983) encoding neomycin phosphotransferase II (nptll) conferring kanamycin resistance, driven by NOS promoter and NOS terminator. The bacterium also contains plasmid pAL4404 which is a disarmed Ti plasmid $(132 \mathrm{KDa})$ containing the virulence genes. For the confirmation of transgenes, calli were taken from the growing callus mass for DNA isolation. PCR- and Southern analysis was performed to determine the integration and the copy number of the transgene. The GUS-test was performed to demonstrate $\beta$-glucuronidase expression. The transgenic plantlets were kept in a hardening room for four weeks and they will be transferred to a growth chamber with controlled environment for further establishment.
\end{abstract}

Keywords: Date palm, Phoenix dactylifera, Genetic transformation, Agrobacterium rhizogenes, Agrobacterium tumefaciens

\section{Introduction}

Date palm (Phoenix spp) is important fruit for the people of Bangladesh, and historically has been associated with their religion, culture, rites, and rituals. Bangladesh has high varietal diversity of wild relatives of this species. These are food-cum-cash and also cottage industrial plants in Bangladesh. They are very popular and allowed to grow in Bangladesh mainly for fruit, its sweet sap and molasses. Molasses prepared from Date palm is sweeter than sugarcane molasses due to its higher reducing sugar content, and very popular for its special taste and aroma. It contains more protein, fat, mineral specially phosphorus and calcium than sugarcane molasses. In addition to the drinking of sap, molasses and cake making the Date palm is used in many other ways, viz. as fuel, timber, building materials, mat etc. Fruits have medicinal value. Arabian Dates are much popular, and consumed in large quantity in Bangladesh are imported mostly from Arabian countries and Pakistan in exchange of huge foreign currency. Important traits such as tolerance to flooding, cold, high temperature, submergence, salinity, drought, diseases and insect resistance, having good eating qualities and above all, wider adaptability in land races are desirable for the improvement of this valuable crop. 
Conventional plant breeding methods alone are insufficient to incorporate desirable traits in locally cultivated exotic and local varieties of date palm. However, the application of genetic engineering (gene technology) will be able to contribute significantly to combat the situation. This technique offers the potential for the introduction of specific genes from any source (related or unrelated plant species or even from animal) into the existing elite plant lines. Thus genetic transformation provides an exciting new technology to supplement traditional crop improvement procedures and together these approaches should accelerate the development of new plant variety, which is not possible through breeding and tissue culture alone. This technique offers the ability to introduce single new character into a plant cultivar without altering of its existing traits i.e. recombinant DNA technologies has tremendous potential in crop improvement applications (Hansen, 1999). Therefore, it is essential to develop a DNA delivery system for the introduction of desired characteristics in the exotic and local varieties of these cultivated species. And to do such a well adapted regeneration and transformation protocol of Phoenix spp must have to be developed using the locally cultivated varieties of Bangladesh.

It may be mentioned here that no attempt has been taken to establish in vitro regeneration protocol for Phoenix spp in Bangladesh. Recently, we have stated this work to improve the locally grown promising cultivars and establish a suitable, stable, efficient and reproducible protocol for transformation and regeneration of plantlets of Phoenix spp.

\section{Materials and Methods}

\section{Explants}

Identification of the proper explant for transformation experiments plays a vital role in order to obtain a high frequency of transformation and regeneration. Based on several reports on published and unpublished work on regeneration in Phoenix genus the off-shoot segments were used for transformation with Agrobacterium rhizogenes.

\section{Agrobacterium rhizogenes-mediated transformation}

A protocol was developed for efficient, rapid and stable transformation of two exotic and eight local varieties of Phoenix spp. Off-shoot segments were submerged in $70 \%$ ethanol for 2 minutes and then for 25 minutes in $0.1 \%$ mercuric chloride. Offshoot segments of each genotype were placed in vials containing MS media and kept in a growth room for maintaining proper condition of the plant growth. We took only the youngest parts of the plant. The basal end of the segments were inoculated with the Agrobacterium rhizogenes strains LBA 9402. For cotransformation experiments the strain LBA 9402 with the binary vector pBIN19 with the p35S GUS INT gene (Vancanneyt et al., 1990) was used. The explants were then dipped in MS-medium with one-half of the usual strength. The upper end of the explants was dipped in the medium in such a way so that the inoculated cut surface is exposed on the upper side. After 15-20 days hairy roots, $0.5-0.6 \mathrm{~cm}$ long, were excised and treated with a liquid callus-inducing medium (C23y) (Guerche et al. 1987) for further growth along with a control for three days. After that they were placed on regeneration medium (N5 medium) with antibiotics $(500 \mathrm{mg} / \mathrm{L}$ carbenicillin and $200 \mathrm{mg} / \mathrm{L}$ claforan). The GUS staining was carried out according to Jefferson et al. (1987). Roots were incubated in $\mathrm{X}$-Gluc for $16 \mathrm{hr}$ at $37^{\circ} \mathrm{C}$. PCR and southern analysis using the rolC gene as a probe were applied to confirm the presence of the Ri-TL-DNA in transformed plants.

\section{Agrobacterium tumefaciens-mediated transformation}

A protocol was developed for efficient, rapid and stable transformation of two exotic and eight local varieties of Phoenix spp. using Agrobacterium tumefaciens as vector. Offshoot segments were submerged in $70 \%$ ethanol for 2 minutes and then for 25 minutes in $0.1 \%$ mercuric chloride. After sterilization the offshoots were cut into $2 \mathrm{~cm}$ segments, co-cultivated with the bacterial strain along with the plasmids and placed on regeneration medium. MS media were supplemented with different combinations of phytohormones for regeneration. Calli were initiated from the offshoot segments on MS medium supplemented with phytohormones, solidified with $5 \mathrm{~g} / \mathrm{l}$ of agar after adjusting the $\mathrm{pH}$ to 5.7 under continuous dark at $30^{\circ} \mathrm{C}$. 
Agrobacterium tumefaciens strains: I) GV3101 with the vir plasmid pMP90 the strain C58C1 ATHV with the vir-plasmid pTiBo542 (=pEHA101; Hood et al. 1986), a strain similar to EHA101 which has been shown to be highly virulent for many of the important leguminous crops (Jin et al. 1997, Hood et al. 1987) was used. The nptll gene (neomycin phosphotransferase) was used as a selectable marker gene. The $\beta$ Glucuronidase-gene (GUS-Gene: Jefferson et al. 1987) under control of the Ubi- and 35S-Promotors, with an Intron (Vancanneyt et al. 1990), was used as the reporter gene.

We also used genetically engineered Agrobacterium tumefaciens strain LBA4404 as a vector for infection in the transformation experiment which contains plasmid pBI121 of $14 \mathrm{KDa}$ (binary vector). This binary vector contains following genes within the right border (RB) and left border (LB) region of the construct:

i. The udiA gene (Jefferson, 1986) predetermining GUS ( $\beta$-glucuronidase), driven by CaMV promoter and NOS terminator. This reporter gene can be used to assess the efficiency of transformation.

ii. The nptll gene encoding neomycin phosphotransferase II (nptIl) conferring kanamycin resistance, driven by NOS promoter and NOS terminator.

The bacterium also contains plasmid pAL4404 which is a disarmed Ti plasmid (132 KDa) containing the virulence genes.

For the confirmation of transgenes, calli were taken from the growing callus mass for DNA isolation. PCRand Southern analysis was performed to determine the integration and the copy number of the transgene. The GUS-test was performed to demonstrate ß-glucuronidase expression of the inserted genes.

\section{Agrobacterium culture and inoculation}

Two different types of culture media, namely, YMB (Yeast extract Mannitol Broth) medium, LB (Luria Broth) medium were used with kanamycin as antibiotic to grow the strain of genetically engineered Agrobacterium tumefaciens. Here two different media were used viz., Agrobacterium maintenance medium and Agrobacterium working culture medium for transformation.

For maintaining transformation and regeneration protocol preculture, co-cultivation post-cultivation, callus induction, and selection were done.

\section{Results and Discussion}

Using the off-shoot segments as explants we compared in this experiment the responses of two exotic and eight locally collected and cultivated date palm genotypes namely Arabian 1, Arabian 2, Faridpuri -1, Faridpuri-2, Faridpuri-3, Swarupkathi, Jessori-1, Jessori-2, Ishwardi and Jalkathi to A. rhizogenes transformation. Among the genotypes Arabian-2 (63\%), Jalkathi (59\%) and Jessori-1 (58\%) showed better root formation in comparison to other Cultivars (Table 1). Arabian-2 (6.9) showed the highest numbers of 'hairy roots' per off-shoot segment (Table 2). However, other cultivars e.g. Jalkathi (6.1) and Arabian-1 (4.8) also responded quite well. Interestingly, the numbers of 'hairy roots' produced by the genotype Faridpuri-2 is quite low (3.4 roots per segment in mean). Furthermore, most of the genotypes with a high frequency of explants with 'hairy roots' also showed a large number of 'hairy roots' per segment (Fig. 1a). Root length was also varied in respect of genotypes. Results in each interval showed that Arabian-2 performed best up to 28 days followed by Jessore-2 (Table 3). 
Table 1. Effect of different genotypes on root initiation from Agrobacterium rhizogenes infected offshoot segments

\begin{tabular}{|l|c|c|c|c|c|c|c|c|c|}
\hline & \multicolumn{3}{|c|}{$\begin{array}{c}7 \text { Days after } \\
\text { explantation }\end{array}$} & \multicolumn{2}{c|}{$\begin{array}{c}\text { 14 Days after } \\
\text { explantation }\end{array}$} & \multicolumn{2}{c|}{$\begin{array}{c}21 \text { Days after } \\
\text { explantation }\end{array}$} & \multicolumn{2}{c|}{$\begin{array}{c}28 \text { Days after } \\
\text { explantation }\end{array}$} \\
\hline Materials & $\begin{array}{c}\text { No. of } \\
\text { explants } \\
\text { incubated }\end{array}$ & $\begin{array}{c}\text { No. of } \\
\text { explants } \\
\text { producing } \\
\text { root }\end{array}$ & $\begin{array}{c}\% \text { root } \\
\text { induction }\end{array}$ & $\begin{array}{c}\text { No. of } \\
\text { explants } \\
\text { producing } \\
\text { root }\end{array}$ & $\begin{array}{c}\% \text { root } \\
\text { induction }\end{array}$ & $\begin{array}{c}\text { No. of } \\
\text { explants } \\
\text { producing } \\
\text { root }\end{array}$ & $\begin{array}{c}\% \text { root } \\
\text { induction }\end{array}$ & $\begin{array}{c}\text { No. of } \\
\text { explants } \\
\text { producing } \\
\text { root }\end{array}$ & $\begin{array}{c}\% \text { root } \\
\text { induction }\end{array}$ \\
\hline Arabian-1 & 50 & 14 & 20 & 19 & 33 & 24 & 42 & 24 & 42 \\
\hline Arabian-2 & 50 & 18 & 38 & 26 & 52 & 31 & 63 & 31 & 63 \\
\hline Faridpuri-1 & 50 & 11 & 22 & 17 & 34 & 21 & 42 & 21 & 42 \\
\hline Faridpuri-2 & 50 & 09 & 17 & 12 & 25 & 14 & 29 & 14 & 29 \\
\hline Faridpuri-3 & 50 & 08 & 16 & 11 & 22 & 14 & 28 & 14 & 28 \\
\hline Swarupkathi & 50 & 9 & 18 & 15 & 30 & 18 & 36 & 18 & 36 \\
\hline Jessori-1 & 50 & 14 & 28 & 21 & 42 & 29 & 58 & 29 & 58 \\
\hline Jessori-2 & 50 & 13 & 26 & 26 & 44 & 28 & 49 & 28 & 49 \\
\hline Ishwardi & 50 & 15 & 30 & 20 & 40 & 25 & 50 & 25 & 50 \\
\hline Jalkathi & 50 & 16 & 33 & 26 & 52 & 30 & 59 & 30 & 59 \\
\hline
\end{tabular}

Table 2. Effect of different genotypes on root number from Agrobacterium rhizogenes infected offshoot segments

\begin{tabular}{|l|c|c|c|c|}
\hline \multirow{2}{*}{ Genotypes } & \multicolumn{4}{|c|}{ Number of roots per explant } \\
\cline { 2 - 5 } & $\begin{array}{c}\text { 7 Days after } \\
\text { explantation }\end{array}$ & $\begin{array}{c}\text { 14 Days after } \\
\text { explantation }\end{array}$ & $\begin{array}{c}\text { 21 Days after } \\
\text { explantation }\end{array}$ & $\begin{array}{c}\text { 28 Days after } \\
\text { explantation }\end{array}$ \\
\hline Arabian-1 & $2.2 \mathrm{bc}$ & $3.9 \mathrm{~b}$ & $4.8 \mathrm{~b}$ & $4.8 \mathrm{~b}$ \\
\hline Arabian-2 & $3.8 \mathrm{a}$ & $6.1 \mathrm{a}$ & $6.9 \mathrm{a}$ & $6.9 \mathrm{a}$ \\
\hline Faridpuri-1 & $2.4 \mathrm{bc}$ & $3.6 \mathrm{~b}$ & $4.2 \mathrm{~b}$ & $4.2 \mathrm{~b}$ \\
\hline Faridpuri-2 & $1.6 \mathrm{c}$ & $3.2 \mathrm{~b}$ & $3.4 \mathrm{~b}$ & $3.4 \mathrm{~b}$ \\
\hline Faridpuri-3 & $2.4 \mathrm{bc}$ & $3.8 \mathrm{~b}$ & $4.4 \mathrm{~b}$ & $4.4 \mathrm{~b}$ \\
\hline Swarupkathi & $1.9 \mathrm{bc}$ & $3.4 \mathrm{~b}$ & $4.3 \mathrm{~b}$ & $4.4 \mathrm{~b}$ \\
\hline Jessori-1 & $2.0 \mathrm{bc}$ & $3.8 \mathrm{~b}$ & $4.4 \mathrm{~b}$ & $4.6 \mathrm{~b}$ \\
\hline Jessori-2 & $1.8 \mathrm{bc}$ & $3.8 \mathrm{~b}$ & $4.2 \mathrm{~b}$ & $4.4 \mathrm{~b}$ \\
\hline Ishwardi & $2.7 \mathrm{~b}$ & $3.7 \mathrm{~b}$ & $3.8 \mathrm{~b}$ & $3.9 \mathrm{~b}$ \\
\hline Jalkathi & $3.6 \mathrm{a}$ & $5.6 \mathrm{a}$ & $6.1 \mathrm{a}$ & $6.1 \mathrm{a}$ \\
\hline
\end{tabular}

Table 3. Effect of different genotypes on root length from Agrobacterium rhizogenes infected offshoot segments

\begin{tabular}{|l|l|l|l|l|}
\hline \multirow{2}{*}{ Genotypes } & \multicolumn{3}{|c|}{ Root length } \\
\cline { 2 - 5 } & $\begin{array}{l}\text { 7 Days after } \\
\text { explantation }\end{array}$ & $\begin{array}{l}\text { 14 Days after } \\
\text { explantation }\end{array}$ & $\begin{array}{l}\text { 21 Days after } \\
\text { explantation }\end{array}$ & $\begin{array}{l}\text { 28 Days after } \\
\text { explantation }\end{array}$ \\
\hline Arabian-1 & $0.208 \mathrm{~h}$ & $0.333 \mathrm{e}$ & $0.559 \mathrm{f}$ & $0.783 \mathrm{~d}$ \\
\hline Arabian-2 & $0.295 \mathrm{a}$ & $0.511 \mathrm{a}$ & $0.793 \mathrm{a}$ & $0.991 \mathrm{ab}$ \\
\hline Faridpuri-1 & $0.251 \mathrm{~d}$ & $0.427 \mathrm{bc}$ & $0.617 \mathrm{de}$ & $0.937 \mathrm{bc}$ \\
\hline Faridpuri-2 & $0.225 \mathrm{f}$ & $0.365 \mathrm{de}$ & $0.575 \mathrm{ef}$ & $0.851 \mathrm{~cd}$ \\
\hline Faridpuri-3 & $0.224 \mathrm{f}$ & $0.324 \mathrm{e}$ & $0.621 \mathrm{~d}$ & $0.950 \mathrm{bc}$ \\
\hline Swarupkathi & $0.209 \mathrm{~h}$ & $0.387 \mathrm{~cd}$ & $0.686 \mathrm{c}$ & $0.910 \mathrm{c}$ \\
\hline Jessori-1 & $0.264 \mathrm{c}$ & $0.417 \mathrm{bc}$ & $0.748 \mathrm{~b}$ & $1.057 \mathrm{a}$ \\
\hline Jessori-2 & $0.284 \mathrm{~b}$ & $0.452 \mathrm{~b}$ & $0.772 \mathrm{ab}$ & $0.983 \mathrm{ab}$ \\
\hline Ishwardi & $0.228 \mathrm{e}$ & $0.334 \mathrm{e}$ & $0.646 \mathrm{~cd}$ & $0.892 \mathrm{c}$ \\
\hline Jalkathi & $0.222 \mathrm{~g}$ & $0.388 \mathrm{~cd}$ & $0.678 \mathrm{c}$ & $0.866 \mathrm{~cd}$ \\
\hline
\end{tabular}


This experiment revealed quite large genotypic differences in the ability to form 'hairy roots' after $A$. rhizogenes transformation, indicating that in some genotypes the transformation may be problematic.

To investigate this in detail we performed a co-transformation experiment with $A$. rhizogenes carrying a binary plasmid with a 35S-GUS-Intron and off-shoot segments as explants. The GUS-staining of the 'hairy roots' (Fig 1b) showed that the cotransformation rate was in the range $90-100 \%$ (data not shown). From the later two experiments, we concluded that the transformation process itself does not have any problem in most of the tested genotypes. Spontaneous or 2,4-D induced callus development occurred reproducible at a high frequency (up to 100\%) from every genotype tested. However, no plantlet regeneration was possible on shoot regeneration medium till now.

The genotype Arabian-2 showed to be the most responsive variety for Agrobacterium rhizogenes transformation in Phoenix spp. The observed high co-transformation rates showed that this system is suitable for the easy and fast production of transgenic roots and callus. However, the transformation experiments using $A$. rhizogenes are in progress and seemed to be slow, because of the lack of a working in vitro plantlet regeneration system from callus. Further experiments has been concentrated on the $A$. tumefaciens mediated transformation, since in that system the regeneration is not influenced by the gene products of the rol-loci ('root locus' of $A$. rhizogenes), which alter the endogenous phytohormone level.

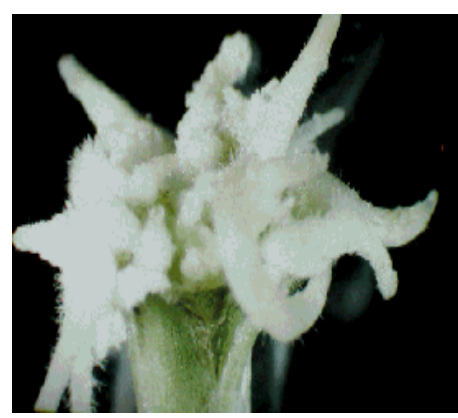

a

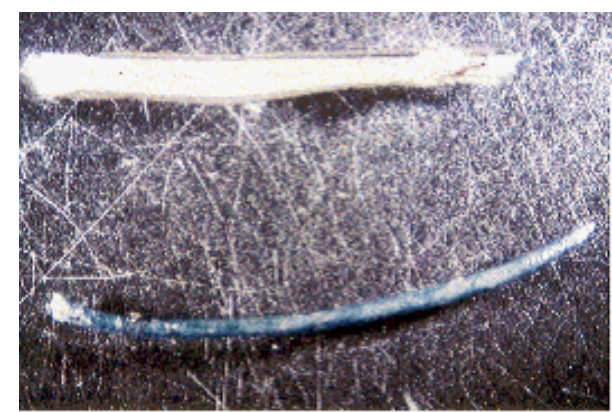

b

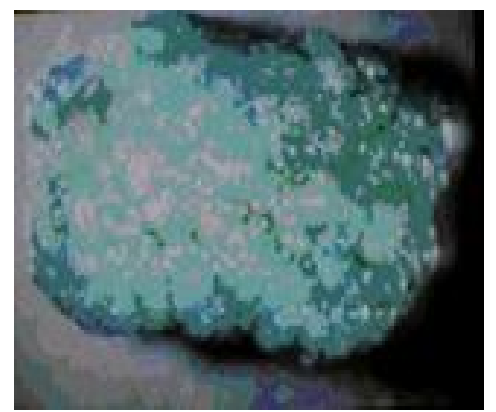

C

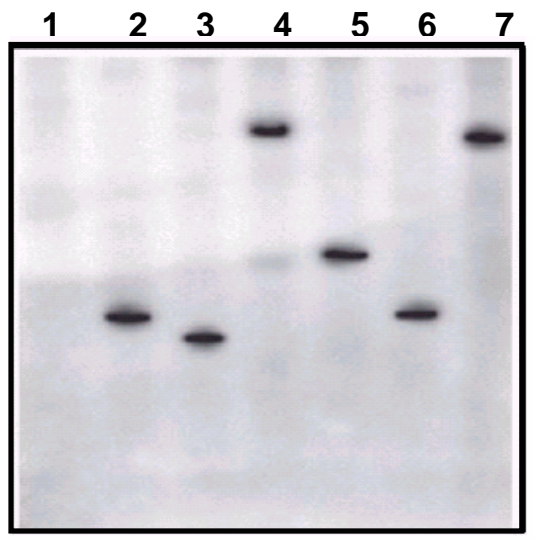

d

Fig 1 (a-d) Agrobacterium-mediated transformation in date palm: a. Hairy roots formation via Agrobacteriumrhizogenes, b. GUS $(X-G / u c)$ assay of potential transgenic root material transformed via $A$. rhizogenes, c. GUS $(X-$ Gluc) assay of potential transgenic root material transformed via $A$. tumefaciens, d. Southern blot analysis of DNA isolated from young leaves of non-transformed control (lane 1), transformed Arabian-1 (lane-2), transformed Arabian2 (lane-3), transformed Faridpuri-3 (lane 4), transformed Jalkathi (lane 5), transformed Jessore-1 (lane 6), undigested plasmid DNA (positive control) (lane7). 
An efficient, stable and reproducible Agrobacterium tumefaciens-mediated transformation protocol was developed for two exotic and eight local varieties of Phonix spp. Regeneration itself does not represent any problem. Off-shoot leaf segments proved to be the best explants. Shoot regeneration in Agrobacterium rhizogenes-mediated transformation was not possible till now. In Agrobacterium tumefaciens-mediated transformation transgenic, friable calli has been obtained in culture and histochemical GUS assay confirmed the intergration of GUS gene (Fug 1c). MS media supplemented with $2 \mathrm{mg} / \mathrm{l} 2,4-\mathrm{D}+0.3 \mathrm{~g} / \mathrm{l}$ activated charcoal showed the best results in regenerating the transformants. The transformed shoots were kept in a controlled environment for hardening for four weeks. They will be transferred to a growth chamber with controlled environment for further establishment.

Southern analysis of five putative transgenic plants (Arabian-1, Arabian-2, Faridpuri-3, Jalkathi, Jessore1 ) confirmed the integration of GUS gene. DNA isolated from the non-transformed plants did not hybridise with the GUS probe (Fig. 1d).

Transformation itself and callus formation do not have any problem. But subsequent regeneration from the roots/calli represents the major bottle neck of the experiment with Agrobacterium rhizogenesmediated transformation. We would like to continue the experiment to look into the performance of various media and phytohormones. Some additives like (amino acids, activated charcoal, vitamins) may have some role on shoot production from the hairy roots. Agrobacterium tumefaciens-mediated transformation seemed to be successful and the transformation protocol will be utilised for the delivery of gene construct with desired characters in exotic and local varieties of date palm. The transgenic date palm varieties will be used by the farmers and/or by the industry that will play important role in sustainable agriculture.

\section{Acknowledgements}

The author is grateful to Professor Heiko C. Becker and Dr. Christian Möller of Göttingen University, Germany for providing the bacterial strains and plasmids for conducting this experiment. The work has been supported by the Ministry of Science \& Technology, Government of Bangladesh under the project No. Biprom/Sha-9/Bi;Anu:pro:/B.S-1/516.

\section{References}

Guerche, P., Jouanin, L., Tepfer, D. and Pelletier, G. 1987. Genetic transformation of oilseed rape (Brassica napus) by the Ri TDNA of Agrobacterium rhizogenes and analysis of inheritance of the transformed phenotype. Mol. Gen. Genet. 206, 382386.

Hansen, G., and Wright, M.S. 1999. Recent advances in transformation of agricultural plants. Trends Plant Sci. 4:226-231.

Hood, E.E., Helmerm, G.L., Fraleym, R.T. and Chiltonm, M.D. 1986. The hypervirulence of A. tumefaciens A 281 is encoded in a region of pTiBo542 outside of T-DNA. J. Bacteriol. 168, 1291-1301.

Hood, E.E., Fraley, R.T. and Chilton, M.D. 1987. Virulence of Agrobacterium tumefaciens, strain A 281 on legumes. Plant Physiol. 83, 529-534.

Jefferson, R.A., Kavanagh, T.A. and Bevan, M.W. 1987. Gus fusion: beta-glucuronidase as a sensitive and versatile gene fusion marker in higher plants. EMBO J. 6(13), 3901-3907.

Jin, S., Komari, T., Gordon, M.P. and Nester, E.W. 1997. Genes responsible for the supervirulence phenotype of $A$. tumefaciens AA281. J. Bacteriol. 169, 4417-4425.

Vancanneyt, G., Schmidt, R., O‘Connor-Sanchez, A. and Willmitzer, L. 1990. Construction of an intron-containing marker gene: Splicing of the intron in transgenic plants and its use in monitoring early events in Agrobacterium-mediated plant transformation. Mol. Gen. Genet. 220, 245-250. 